\title{
Experimental examination of the effects of rainwater on microbial communities in the surface layer of the NW Mediterranean Sea
}

\author{
C. Klein*, J. R. Dolan, F. Rassoulzadegan \\ Marine Microbial Ecology Research Group, CNRS URA 2077, Station Zoologique, BP 28, \\ F-06230 Villefranche-sur-Mer, France
}

\begin{abstract}
The effect of rain-borne nutrients in spring on the marine microbial community was studjed in Villefranche Bay (France), a system in which previous studies have suggested that competition exists within the microbial food web for nutrient salts. In 5 incubation experiments, conducted from May 1994 to March 1996, surface seawater was amended with 2 to $8 \%$ (v/v) rainwater additions. The additions yielded final nutrient concentrations from 0.98 to $5.93 \mu \mathrm{M}$ of dissolved inorganic nitrogen $\left(\mathrm{NH}_{4}{ }^{+}+\mathrm{NO}_{3}{ }^{-}\right.$forms) and 0 to $0.05 \mu \mathrm{M}$ of inorganic phosphorus $\left(\mathrm{PO}_{4}{ }^{3-}\right)$. In 4 out of 5 experiments, significant increases in chlorophyll a $\left(\mathrm{chl}\right.$ a) were detected. The ratio of added $N\left(\mu g \mathrm{l}^{-1}\right)$ to apparent increase in $\mathrm{chl} \mathrm{a}\left(\mathrm{\mu g} \mathrm{l}^{-1}\right)$ averaged about 100. The increases in chl a were correlated with increases in abundances of phototrophic nanoflagellates (PNAN). In contrast to chl a and PNAN stocks, no effect of rainwater addition was evident among the populations of autotrophic bacteria (Synechococcus $\mathrm{sp}$.), heterotrophic bacteria, or the predators of bacteria, heterotrophic nanoflagellates. In one experiment, there was no significant effect of rainwater addition; however, nutrient concentrations of unamended

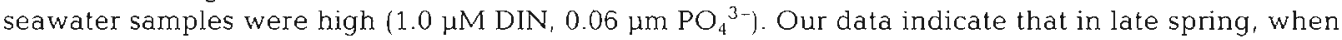
the NW Mediterranean is most likely nitrogen limited, rain-borne 'new nutrients' appear to benefit small eucaryotic phytoplankton, PNAN, rather than autotrophic or heterotrophic bacterial populations or larger phytoplankton.
\end{abstract}

KEY WORDS: Nitrogen $\cdot$ Rain $\cdot$ Bacterioplankton $\cdot$ Phytoplankton $\cdot$ Synechococcus

\section{INTRODUCTION}

The atmosphere has long been known as a route for the delivery of dissolved inorganic nitrogen (DIN) to marine surface waters (Menzel \& Spaeth 1962, Duce 1986, Löye-Pilot et al. 1990). Since most oceanic waters are assumed to be principally N-limited (Ryther \& Dunstan 1971, Codispoti 1989), interest in the fate of these nutrient inputs has been growing (Fanning 1989, Duce et al. 1991) in part, at least, due to concern over the ecological consequences of increasing emissions of $\mathrm{N}$-based compounds to the atmosphere (Buijsman et al. 1987, Paerl et al. 1990, Fisher \& Oppenheimer 1991, Paerl 1993).

\footnotetext{
•E-mail: klein@ccrv.obs-vlfr.fr
}

Increases in nitrate concentration following rainfall events have been noted by many investigators, and the conclusion has been drawn that precipitation delivers detectable amounts of new nutrients to marine surface waters (e.g. for the NW Mediterranean: Bernard 1956, Selmer et al. 1993). Similarly, following rainfall events, increases in chlorophyll a (chl a) concentrations (Martin et al. 1989) as well as near surface phytoplankton blooms (Owens et al. 1992, Mallin et al. 1993) have been reported.

However, there is little consensus concerning the general importance of such nutrient inputs. It has been argued that, over large time and space scales (e.g. annual and basin-wide scales), the quantities of DIN delivered via the atmosphere are very small relative to the stocks of nitrogen (Knap \& Jickells 1986). Nonetheless, there is a growing body of evidence arguing for 
the importance of atmospheric input over short time scales (Donaghay et al. 1991, Michaels et al. 1993, Spokes et al. 1993), in particular in oligotrophic areas where surface waters are nutrient poor (Willey \& Cahoon 1991, Owens et al. 1992, Rendell et al. 1993, Jickells 1995). Furthermore, any input from the atmosphere represents the delivery of nutrients which are 'new' to the system.

In recent years, the conceptual division of primary production into ' $n$ ew', as based on nutrients imported into the surface layer (new nutrients), in contrast to 'old', as based on nutrients recycled within the surface layer (Dugdale \& Goering 1967), has become commonly accepted (e.g. Eppley \& Peterson 1979, Eppley 1989). New production is considered to be equivalent to production, or matter, exported out of the surface ocean to deeper layers. Over a global scale, the nitrogen supplied by atmospheric deposition may support from 8 to $70 \%$ of such 'new' production in various offshore as well as coastal and estuarine waters (Duce 1986, Paerl et al. 1990, Fisher \& Oppenheimer 1991, Paerl 1993).

In the Mediterranean Sea, as in other enclosed seas, atmospheric deposition of nutrients is probably an important term in nutrient budgets (Paerl 1995). For example, consideration of nitrogen budgets and annual surveys of wet precipitation has led to the suggestion that wet deposition of DIN could support from 25 up to $60 \%$ of estimated new production (Loÿe-Pilot. \& Morelli 1988, Migon et al. 1989, Loÿe-Pilot et al. 1990) and perhaps as much as $70 \%$ if DIN dry deposition is included (C. Klein unpubl.).

The utilisation of newly available rain-borne nutrients has been investigated in bioassays, primarily in areas of the North Atlantic. These studies have focused exclusively on phytoplankton and have found significant effects, in terms of ${ }^{14} \mathrm{C}$ fixation and increases in chlorophyll stocks, in samples of sea surface water enriched with 0.5 to $20 \%$ (v/v) rainwater (Paerl 1985, Paerl et al. 1990, Willey \& Cahoon 1991, Willey \& Paerl 1993, Paerl \& Fogel 1994). However, to our knowledge, no studies have attempted to assess the response of phytoplankton to atmospheric deposition in Mediterranean waters, where atmospheric deliveries are probably proportionately more important than in the North Atlantic. Surprisingly, no previous studies have attempted to determine which part of the phytoplankton community may respond to wet deposition or considered possible effects on other components of the microbial food web.

Such data is of great interest because carbon and energy transfer to the higher levels of the marine food webs is dependent upon on the structure and composition of the microbial compartment (Azam et al. 1983, Pomeroy \& Wiebe 1988). Of particular importance is the average size of the dominant primary producers because little matter is exported out of the surface layer, or passed on to higher trophic levels, when primary production is essentially due to small phytoplankton (Rassoulzadegan 1993, Legendre \& Rassoulzadegan 1995, 1996). For example, the small cyanobacteria (approx. $1 \mu \mathrm{m}$ in diameter) are generally thought to be consumed by protists such as heterotrophic nanoflagellates and ciliates while the larger photosynthetic flagellates and diatoms can be consumed directly by copepods, the next higher trophic level (e.g. Sherr et al. 1986). Small, transient increases in nitrate concentration, such as might be expected from rain events, have been associated with blooms of of the small cyanobacteria Synechococcus (Glover et al. 1988)

Currently, it is well recognised that not only autotrophic but also heterotrophic bacteria are an important component of planktonic food webs. In oligotrophic systems, such as the NW Mediterranean, heterotrophic bacteria, like phytoplankton, can be limited by inorganic nutrients and bacteria can act as efficient competitors of phytoplankton for scarce nutrients (e.g. Dolan et al. 1995). In waters in which bacteria are nutrient limited rather than carbon limited, dissolved organic carbon can accumulate, which is apparently the case for the NW Mediterranean (Thingstad \& Rassoulzadegan 1995, Thingstad et al. 1997).

Experimental studies of the natural bacterial communities in the Bay of Villefranche (France) have shown that growth rates can increase in the presence of the excretory products of protists (Ferrier-Pagès \& Rassoulzadegan 1994). When the bacterial community is released from nutrient limitation, the consumption of dissolved organic carbon is stimulated (Zweifel et al. 1993). As bacterioplankton in the NW Mediterranean are apparently often limited by inorganic nutrients, rather than dissolved organic carbon (Thingstad et al. 1998), the addition of nutrients may result in a net respiration of carbon through the activities of bacteria rather than a fixation of carbon due to the activities of phytoplankton. In this sense, the addition of 'new nutrients' can paradoxically yield an increase in the consumption of carbon rather than the export of carbon. These considerations led us to investigate the effect of rainwater additions on stocks of both heterotrophic and autotrophic populations of bacteria and eucaryotes in the NW Mediterranean.

We focused on the period of the spring-early summer stratification when the system is subjected to periodic heavy rainfall and is most likely to be limited by nitrogen. Previous studies have indicated that from midsummer to late fall the system is phosphorus limited (Berland et al. 1980, Dolan et al. 1995, Thingstad et al. 1998). The basic approach was the use of bioassays in 
which seawater is amended with natural rainwater, which produces increases in nutrient concentrations which are slight relative to traditional nutrient enrichment experiments. Changes in microbial populations were then followed with time. We employed a variety of rain types to encompass the range of natural rainfall events.

\section{METHODS}

Rainwater sampling and analysis. Rainwater was collected in an open area at the Station Zoologique, Villefranche-sur-Mer (France), using plastic collectors prewashed and rinsed with deionised distilled water (DDW). Collectors were set out as rainfall started and retrieved as rapidly as possible at the end of the event (within 6 h).

Among the rainwater samples collected, 6 were used in the bioassays. These samples were characterised (Table 1) according to the classification of rain events established for the western Mediterranean region (Loÿe-Pilot \& Morelli 1988). The main types distinguished are Oceanic, Saharan, Polluted or Composite. Most of the rainwater we used in our bioassays was composite with a polluted component. This type is frequently observed over a yearly scale in this region (Loÿe-Pilot et al. 1990) as a result of surrounding anthropogenic sources (intensive agriculture, industry, urban traffic) in Europe (Table 1).

Rainwater samples were divided into $10 \mathrm{ml}$ aliquots filtered through $0.45 \mu \mathrm{m}$ Millipore filters, and then kept frozen until either chemical analysis or utilisation in the bioassays. The analysis of DIN species employed classic colorimetric methods, the blue indophenol for $\mathrm{NH}_{4}{ }^{+}$(Solarzano 1969) and Na-salicylate for $\mathrm{NO}_{3}{ }^{-}$ (Rodier 1976) Detection limits were 0.3 and $0.5 \mu \mathrm{M}$ respectively, with corresponding 2 and $3 \%$ standard deviations. $\mathrm{PO}_{4}{ }^{3-}$ concentrations were determined with an AutoAnalyser System (EV2-Alliance Instru- ments) according to Tréguer \& Le Corre (1975). Detection limit of this procedure is $0.02 \mu \mathrm{M}$, with $0.01 \mu \mathrm{M}$ standard deviation.

Experimental protocol and analytical procedures. Experimental protocol: Five incubation experiments were carried out from 1994 to 1996, all from April to June, at the Station Zoologique of Villefranche-surMer. We collected surface seawater in polycarbonate bottles at the standard sampling site 'Point B' at the mouth of Villefranche Bay, off the bay of Villefranchesur-Mer $\left(43^{\circ} 41^{\prime} 10^{\prime \prime} \mathrm{N}, 7^{\circ} 19^{\prime} 0^{\prime \prime} \mathrm{E}\right)$. Seawater was immediately brought to the laboratory, where it was screened through a $60 \mu \mathrm{m}$ mesh to remove large zooplankton and transferred into 21 transparent polycarbonate bottles. The bottles had been rinsed and kept filled with $\mathrm{HCl}(10 \%)$ before use, and were rinsed with DDW before every experiment.

Two to 4 sets of triplicate bottles were monitored, including controls and bottles supplemented with rainwater within the 2 to $8 \%(\mathrm{v} / \mathrm{v})$ addition range. In Expts 1 and 3,8\% and 5\% rain treatments were performed respectively (Table 2). In Expts 2 and 4, 2 treatments were simultaneously monitored: $2 \%$ and $5 \%$ in Expt 2 , and $5 \%$ and $8 \%$ in Expt 4 . Finally, we tested 2 different rainwater samples [labelled (a) and (b)] at a $5 \%$ addition level in Expt 5

In each experiment, bottles were incubated in a running seawater bath installed in a semi-shaded area of the dock. Temperature range varied between 16.8 and $23.8^{\circ} \mathrm{C}$ in the different experiments. A $220 \mathrm{ml}$ sample was taken from each bottle at time zero and each day thereafter for $4 \mathrm{~d}$. Final water volume in the bottles was never below half the initial volume.

Analytical procedures: Initial concentrations of $\mathrm{NH}_{4}{ }^{+}, \mathrm{NO}_{3}{ }^{-}$and $\mathrm{PO}_{4}{ }^{3-}$ in surface seawater were determined at the beginning of each experiment using an AutoAnalyser System (EV2-Alliance Instruments) according to Tréguer \& Le Corre (1975). Respective detection limits were $0.02 \mu \mathrm{MPO}_{4}{ }^{3-}, 0.05 \mu \mathrm{M} \mathrm{NO}_{3}{ }^{-}$and $0.05 \mathrm{MM} \mathrm{NH}_{4}{ }^{+}$with $0.01 \mu \mathrm{M}$ standard deviation. Sam-

Table 1. Meteorological and chemical characteristics of the rainwater samples and broassay experiment no. in which they were used

\begin{tabular}{|c|c|c|c|c|c|c|}
\hline \multirow[t]{2}{*}{ Date } & \multirow{2}{*}{$\begin{array}{l}\text { Amount } \\
\text { (cm) }\end{array}$} & \multirow[t]{2}{*}{ Rain type } & \multicolumn{3}{|c|}{ Nutrient conc. $(\mu \mathrm{M})$} & \multirow[t]{2}{*}{ Bioassay } \\
\hline & & & $\mathrm{NO}_{3}^{-}$ & $\mathrm{NH}_{i}^{+}$ & $\mathrm{PO}_{4}{ }^{2-}$ & \\
\hline 25 April 1994 & 2.14 & Composite (Polluted northern sector + Saharan) & 10.8 & 13.8 & 0.19 & Expt 1 \\
\hline 17 May 1994 & 1.07 & Composite (Saharan + Polluted eastern sector) & 42.7 & 30.3 & 1 & Expt 2 \\
\hline 13 May 1994 & 0.55 & Composite (Saharan + Polluted eastern sector) & 78.5 & 40.0 & 1 & Expt 3 \\
\hline $18 \operatorname{Jan} 1995$ & 5.82 & Composite (Polluted northern sector + Oceanic) & 6.0 & 13.5 & $<0.01$ & Expt 4 \\
\hline 13 Apr 1995 (a) & 1.62 & Polluted (a) and (b) & 15.0 & 10.5 & $<0.01$ & Expt 5 \\
\hline 24 Apr 1995 (b) & 3.34 & (eastern and northern sectors) & 13.0 & 6.7 & $<0.01$ & \\
\hline
\end{tabular}


Table 2. Summary information for the 5 experiments. Significance of chl a stimulation: $\cdots p<0.001, " p<0.005$, ns: not significant

\begin{tabular}{|c|c|c|c|c|c|c|c|c|c|}
\hline \multirow[t]{3}{*}{ Expt } & \multirow[t]{3}{*}{ Date } & \multirow{3}{*}{$\begin{array}{l}\% \text { rain } \\
\text { addition }\end{array}$} & \multicolumn{6}{|c|}{ Nutrient conc. $(\mu \mathrm{M})$} & \multirow{3}{*}{$\begin{array}{l}\text { Chl a } \\
\text { stimul. }\end{array}$} \\
\hline & & & \multicolumn{3}{|c|}{ Before rain addition } & \multicolumn{3}{|c|}{ After rain addition } & \\
\hline & & & $\mathrm{NO}_{3}^{-}$ & $\mathrm{NH}_{4}{ }^{*}$ & $\mathrm{PO}_{4}{ }^{3-}$ & $\mathrm{NO}_{3}$ & $\mathrm{NH}_{4}^{+}$ & $\mathrm{PO}_{4}^{3-}$ & \\
\hline 1 & 25 May 1994 & $8 \%$ & 0.1 & $<0.1$ & $<0.01$ & 0.86 & 1.10 & $<0.01$ & $\cdot$ \\
\hline \multirow[t]{2}{*}{2} & 16 Jun 1994 & $2 \%$ & 0.47 & $<0.1$ & $<0.01$ & 1.32 & 0.6 & $<0.01$ & ns \\
\hline & $16 M a y 1095$ & $\begin{array}{l}5 \% \\
5 \%\end{array}$ & 01 & $<01$ & $<001$ & $\begin{array}{l}2.65 \\
3.93\end{array}$ & $\begin{array}{l}1.52 \\
200\end{array}$ & $\begin{array}{l}0.05 \\
0.10\end{array}$ & .. \\
\hline \multirow{2}{*}{4} & 1 Jun 1995 & $5 \%$ & 0.1 & $<0.1$ & $<0.01$ & 0.30 & 0.68 & $<0.01$ & .. \\
\hline & & $8 \%$ & 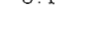 & & & 0.53 & 1.08 & $<0.01$ & .. \\
\hline \multirow[t]{2}{*}{5} & 22 Mar 1996 & $5 \%(a)$ & 0.64 & 0.5 & 0.06 & 1.40 & 1.10 & $<0.01$ & ns \\
\hline & & $5 \%(b)$ & & & & 1.30 & 0.80 & $<0.01$ & ns \\
\hline
\end{tabular}

ples for chl a determinations were filtered onto Whatman GF/F filters before extraction in $90 \%$ acetone (Lorenzen 1966), and chl a concentration was determined by fluorimetry on a Turner Designs fluorometer.

Following Porter \& Feig (1980), formalin-fixed samples ( $3 \%$ final conc.) were DAPI stained (final conc. $0.25 \mu \mathrm{g} \mathrm{ml}^{-1}$ ) and drawn down on black polycarbonate filters $(0.2 \mu \mathrm{m}$ pore size) under low vacuum. Filters were mounted on a slide and examined using epifluorescence microscopy. Slides were examined at a total magnification of $\times 1000$ (Zeiss Axiophot equipment). For heterotrophic bacteria enumeration, 30 fields containing a minimum of 15 bacteria per field were counted. A minimum of 120 cells were counted on transects for the enumeration of heterotrophic (HNAN) and autotrophic (PNAN) nanoflagellates and cyanobacteria (CYANO).

\section{RESULTS}

\section{Nutrients}

DIN concentrations (Table 2) were close to or below the detection limit in initial sea surface water, except in the case of Expt $2\left(0.47 \mu \mathrm{M} \mathrm{NO}_{3}{ }^{-}\right)$and Expt $5(0.6 \mu \mathrm{M}$ $\mathrm{NO}_{3}{ }^{-}$and $\left.0.5 \mu \mathrm{M} \mathrm{NH}{ }_{4}{ }^{+}\right)$. Rainwater enrichment in the 2 to $8 \%$ range yielded final DIN concentration of 0.98 to $5.93 \mu \mathrm{M}$. $\mathrm{PO}_{4}{ }^{3-}$ concentrations in rainwater were below the detection limit $(<0.2 \mu \mathrm{M})$ except in Expts 2 and 3 , in which rainwater contained concentrations of $1 \mu \mathrm{M}$. Thus, water samples amended with rainwater yielded final $\mathrm{PO}_{4}{ }^{3-}$ levels either below the detection limit or not exceeding $0.08 \mu \mathrm{M} \quad 0.05 \mu \mathrm{M}$ in Expt 2 and $0.08 \mu \mathrm{M}$ in Expt 3 with $5 \%$ treatment).

\section{Chlorophyll a}

Initial concentrations of chl a in surface seawater varied between 0.35 and $0.89 \mu \mathrm{g}^{-1}$ (Fig. 1). Within individual experiments, the reproducibility between experimental bottles was good in most cases, with coefficients of variation (CV) among triplicates of less than $15 \%$; but, occasionally higher values $(\geq 20 \%)$ were found at very low chl a concentration ranges (0.10 to $0.05 \mu \mathrm{g} \mathrm{l}^{-1} \mathrm{chl} \mathrm{a}$ ).

A 1 -tailed $t$-test was used to examine the effect of the rainwater treatment on chl $a$. There was a significant treatment effect observed in all the experiments except Expt 5 (Table 2). A common pattern of temporal changes in chl a was noted (Fig. 1). A clear increase appeared after $48 \mathrm{~h}$ and lasted for $2 \mathrm{~d}$ thereafter, though its magnitude decreased the second day in some experiments (e.g. Expt 2, Fig. 1: maximal increase at $48 \mathrm{~h}$ decreased by $25 \%$ at $96 \mathrm{~h}$ ). The magnitude of the chl a enhancement observed varied among the experiments and with the percentage of rain supplemented within the experiment. However, increases in chl a were not linearly related to the amount of DIN added. The ratio of $\mu \mathrm{g}$ nitrogen added to $\mu \mathrm{g}$ chl $a$ increase observed (net increase after $48 \mathrm{~h}$ ) averaged about 100 and ranged from 19 to 173 (Table 3).

Table 3. DIN inputs in bottles supplemented with rain and associated chl $a$ and PNAN changes $(\Delta)$ relative to control after $48 \mathrm{~h}$ incubation

\begin{tabular}{|ccccccc|}
\hline $\begin{array}{l}\text { Expt \% rain } \\
\text { added }\end{array}$ & $\begin{array}{c}\Delta \mathrm{DIN} \\
(\mu \mathrm{M})\end{array}$ & $\begin{array}{c}\Delta \mathrm{DIN} \\
\left(\mu \mathrm{g} \mathrm{I}^{-1}\right)\end{array}$ & $\Delta \mathrm{DIN}: \Delta \mathrm{chl} a$ & $\begin{array}{c}\Delta \mathrm{chl} a \\
\left(\mu \mathrm{gl}^{-1}\right)\end{array}$ & $\begin{array}{c}\Delta \text { PNAN } \\
\left(\mathrm{cells} \mathrm{m}^{-1}\right)\end{array}$ \\
\hline 1 & 8 & 1.86 & 26.04 & 19.1 & 1.36 & 2.48 \\
2 & 5 & 4.17 & 51.8 & 95 & 0.55 & 2.02 \\
3 & 5 & 5.93 & 83.02 & 50.3 & 1.65 & 2.35 \\
4 & 5 & 0.98 & 13.72 & 124.7 & 0.11 & 0.85 \\
& 8 & 1.61 & 22.54 & 173.3 & 0.13 & 0.73 \\
\hline
\end{tabular}



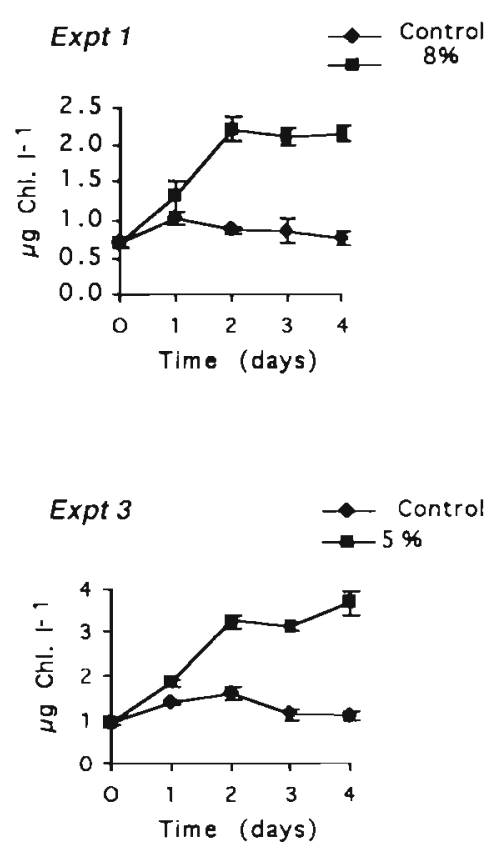

Fig. 1 Temporal changes in chl a concentration in the 5 bioassay experiments. Percentages refer to rain dilution factors, see text and Table 2 for details
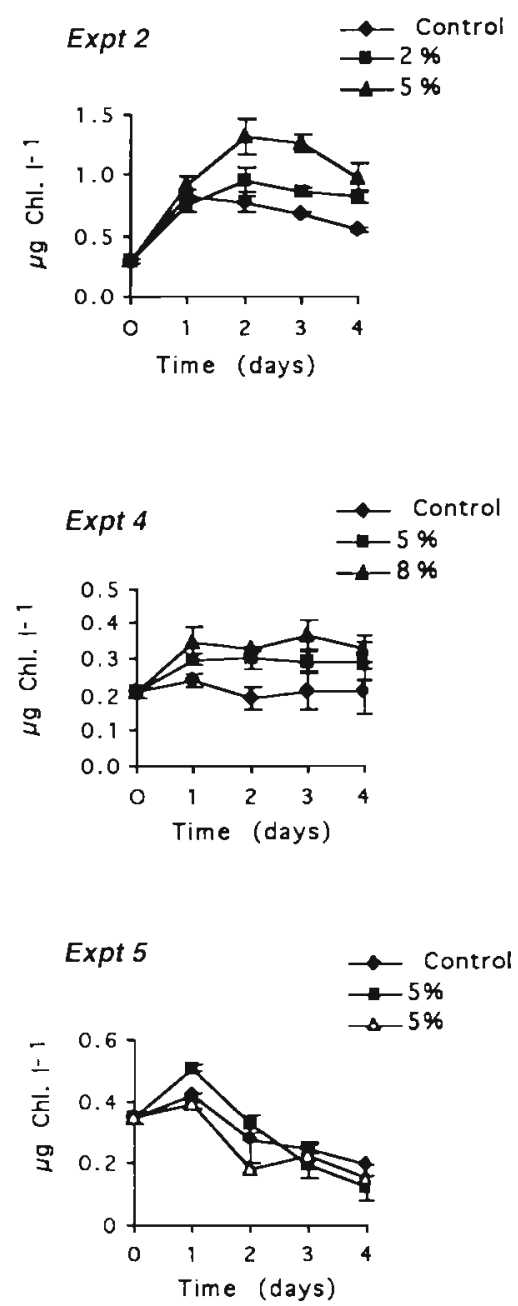

coid with a diameter of mean size around $1 \mu \mathrm{m}$. There was no detectable treatment effect of rain additions on populations of cyanobacteria. Among the experiments, CYANO cell abundance (Fig. 3) varied similarly in both supplemented and control bottles regardless of whether or not the net changes were positive, insignificant or negative.

\section{Heterotrophic nanoflagellates}

Initial HNAN standing stock in seawater varied within a range of 1 to $4 x$ $10^{3}$ cells $\mathrm{ml}^{-1}$. HNAN cell size varied from 2 to $10 \mu \mathrm{m}$, and the dominant size was $4 \mu \mathrm{m}$. As observed for CYANO, HNAN varied similarly in control and rainwater-amended bottles (Fig. 4). Changes in HNAN concentrations with time showed either no specific trend (Expt 1, Fig. 4) or increased the last day (Expts 3 and 4 , Fig. 4 ) by 2 to 3.5 times their initial concentrations. In Expt 3 HNAN increases were associated with large CV values among triplicate bottles (up to 50\%), indicating different developments among HNAN populations.

\section{Heterotrophic bacteria}

\section{Phototrophic nanoflagellates}

Initial PNAN cell abundance in surface seawater at Point B varied from $0.9 \times 10^{3}$ to $5.5 \times 10^{3}$ cells $\mathrm{ml}^{-1}$. PNAN size varied between 3 and $10 \mu \mathrm{m}$ in length, but most cells were approximately $5 \mu \mathrm{m}$ in their largest dimension. The rain treatment effect on PNAN (Fig. 2) appeared within the first $48 \mathrm{~h}$ of incubation in all experiments except Expt 5. Concentrations of PNAN increased 1.2 to 2.2 times relative to controls. In general, temporal changes in PNAN paralleled those of chl $a$ and increases in chl a were correlated with increases in PNAN

\section{Cyanobacteria}

CYANO density in initial surface seawater ranged from 1.7 to $5.5 \times 10^{4}$ cells $\mathrm{ml}^{-1}$. The usual form was coc-
Initial abundances of heterotrophic bacteria in unamended surface seawater ranged between $3.0 \times 10^{5}$ and $10.8 \times 10^{5}$ cells $\mathrm{ml}^{-1}$. Similar to CYANO and HNAN populations, there were no significant differences between treated and untreated bottles. Moreover, in all the experiments, bacterial concentrations remained relatively stable throughout the incubation period (Fig. 5) varying less than $15 \%$.

\section{DISCUSSION}

The majority of our rainwater samples were Composite with a Polluted component attributed to air masses from the eastern and northern sectors of Europe (Table 1). This polluted signature reflects the influence of anthropogenic sources located in northern Europe and Italy. The DIN concentrations in our rain samples varied over a broad range of values from 9.5 to 

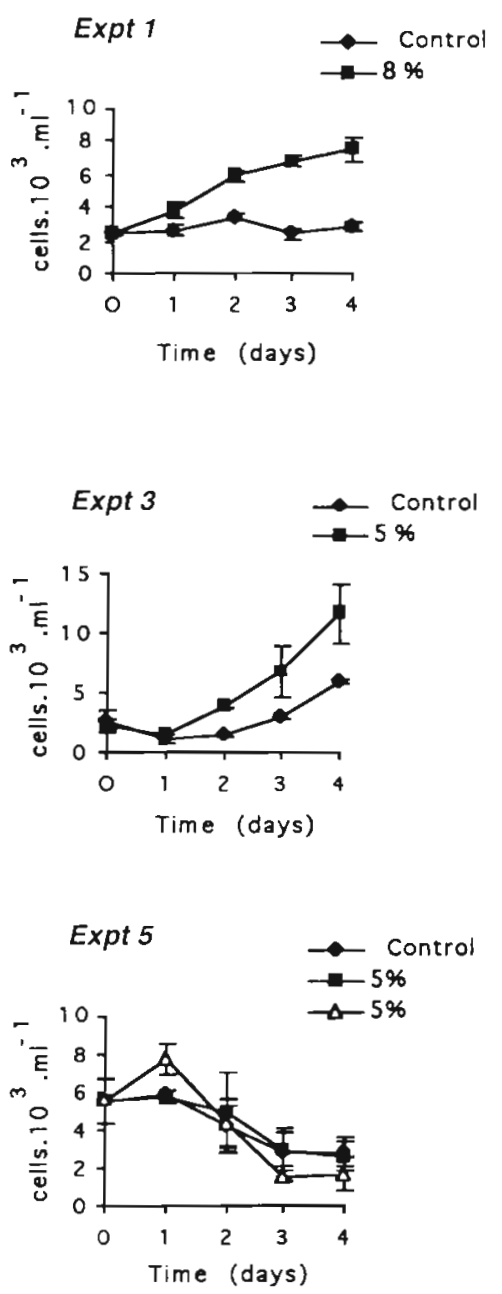
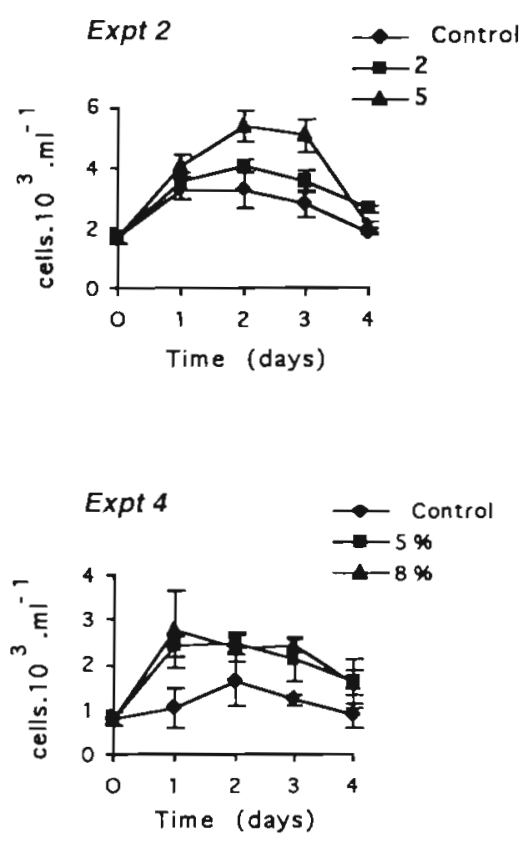

Fig. 2. Temporal changes in abundance of phototrophic nanoflagellates (PNAN) in the 5 bioassay experiments. Percentages refer to rain dilution factors, see text and Table 2 for details

and $P$ in rainwater may have been available for biological processes. There is some evidence in the literature that $\mathrm{PO}_{4}{ }^{3-}$ additions in the nanomolar range can represent a nonnegligible input of nutrients (Suttle et al. 1990). Nonetheless, it should be noted that the nutrient enrichment levels which resulted from the rainwater additions in our experiments were very low relative to typical and previous nutrient enrichment experiments. Traditional nutrient enrichment studies utilise final $\mathrm{N}$ and $\mathrm{P}$ concentrations on the order of $10 \mu \mathrm{M} \mathrm{N}$ and 0.5 to $1 \mu \mathrm{M} P$ (e.g. Fiala et al. 1976. Berland et al. 1978) compared to our additions resulting in 0.6 to $2 \mu \mathrm{M} N$ and $0.1 \mu \mathrm{M} P$.

The dilution treatments we employed, 2 to $8 \%$, fall within the range of treatments used in previous studies with treatments of 0.5 to $20 \%$ dilution values. A $2 \%$ rainwater addition corresponds to the in situ dilution of a $2 \mathrm{~cm}$ rainfall event in the top meter of the water column. Corresponding in situ salinity changes have been linked to such rain events in coastal Atlantic waters (Paerl \& Fogel 1994). Rain events resulting in 2 to $8 \mathrm{~cm}$ of rain are not rare for the Mediterranean region from May to September. We found that increasing the per-

$118.5 \mu \mathrm{M}$. This feature illustrates an observation made previously for this region that DIN values in rainwater depend on the respective influences of Polluted, Saharan and Maritime air masses, which are variable (LoÿePilot et al. 1990). Such variability however is not limited to the Mediterranean, as it has also been noted with regard to atmospheric input reaching the North Atlantic Ocean (Galloway et al. 1984).

Our analysis of rainwater (see Table 1) indicated a general lack of phosphate, relative to nitrogen, as reported by others for the NW Mediterranean (Migon et al. 1989, Bergametti et al. 1992) as well as other systems (Duce 1986, Willey \& Cahoon 1991). An exception was rain with a Saharan contribution (Expts 1, 2 and 3), where $\mathrm{PO}_{4}{ }^{3-}$ concentrations reached $1 \mu \mathrm{M}$. However, in our experiments, $\mathrm{PO}_{4}{ }^{3-}$ final concentrations after the addition of rain were undetectable or very low $(\leq 0.08 \mu \mathrm{M}$ in Expts 2 and 3, see Table 2), so we believe that chl a stimulation we observed resulted mainly from nitrogen enrichment. Nonetheless, we cannot reject the hypothesis that both inorganic forms of $\mathrm{N}$ centage of rain supplied within the same experiment increased the magnitude of the chl a enhancement. The extent of this signal in our experiments varied between a 0.52 and 2.8 -fold chl a increase, quite similar to the 2.5 -fold increase in chl a reported in similar experiments employing a $5 \%$ rainwater addition to Gulf Stream waters (Willey \& Cahoon 1991). In their study, Willey \& Cahoon (1991) reported DIN concentrations representative of natural Continental Event type in the Gulf Stream area and similar to our Polluted type.

In our experiments, increases in chl a were highly correlated with increases in PNAN stocks, with a change in chl $a$ of $1 \mu \mathrm{g}$ corresponding to an increase of about $10^{6}$ PNAN cells on a per liter basis (Fig. 6). While we have no data on the size distribution of the chl $a_{\text {, }}$ the following rough calculations indicate that the observed increase in PNAN likely accounted for most of the increase in chl a. A phytoplankton cell of about $5 \mu \mathrm{m}$ diameter can be expected to contain roughly $1 \mathrm{pg}$ of chl a based on relationships of chl a per unit cell vol- 

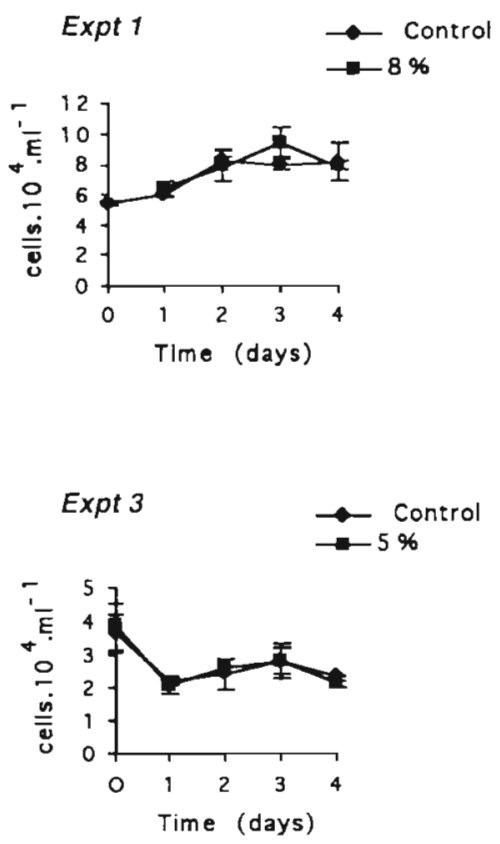

Fig. 3. Temporal changes in abundance of cyanobacteria (CYANO) in the 5 bioassay experiments. Percentages refer to rain dilution factors, see text and Table 2 for details

ume and cell size (Malone 1980). Therefore, an increase of $10^{6}$ cells per liter would yield a $1 \mu \mathrm{g}$ increase in chl $a$, as we observed. Thus, one of our major findings is that stimulation of phytoplankton, noted in previous studies in other systems (e.g. Paerl 1985, Willey \& Cahoon 1991, Willey \& Paerl 1993), was, in our Mediterranean experiments, the result of increases in PNAN stocks.

While our data showed a relatively robust relationship between chl a and PNAN, the quantity of nitrogen added and the increase in chl de-

Fig. 4. Temporal changes in abundance of heterotrophic nanoflagellates (HNAN) in the bioassay experiments, Expt 2 excepted. Percentages refer to rain dilution factors, see text and Table 2 for details
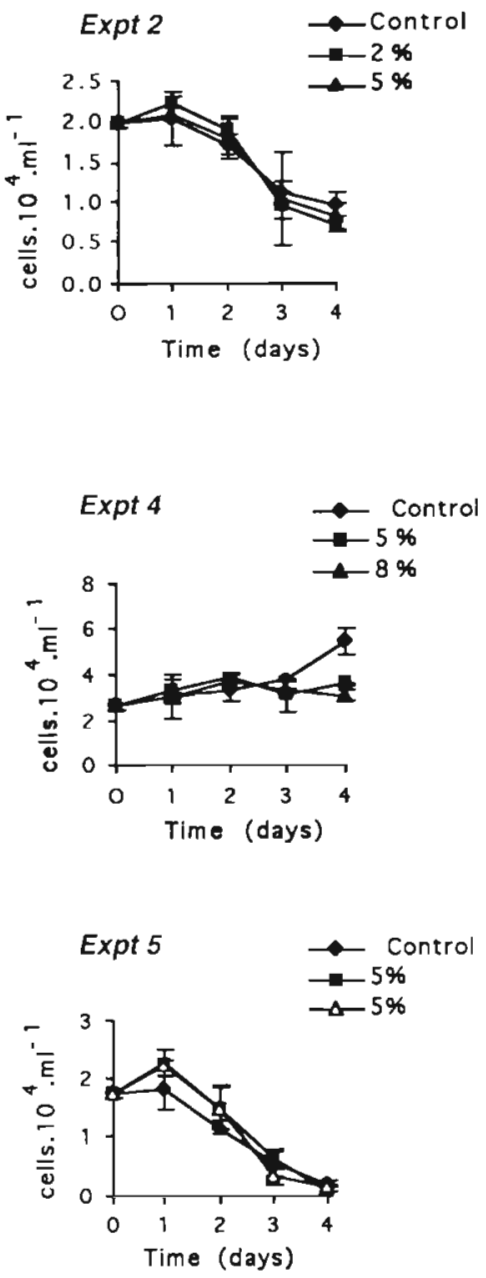

tected were not related in a simple fashion (Table 3 ). This was not surprising, given that chlorophyll to carbon to nitrogen ratios are far from constant even within a given species. For example, a recent chemostat study of Dunaliella tertiolecta showed that $\mathrm{N}$-limited cultures subjected to changes in light regime displayed $\mathrm{N}$ :chl a ratios which shifted by a factor of 3 to 4 (Sciandra et al. 1997). Such considerations underline the hazards of attempting to predict increases in phytoplankton stocks from nutrient additions.

In contrast to photosynthetic eucaryotes, bacterial populations, whether cyanobacteria or heterotrophic bacteria, showed no significant reactions to the addition of rainwater (Figs. 2, 3 \& $4)$. It could be argued that the stability of cyanobacteria and heterotrophic bacteria does not negate their having been stimulated but simply reflects tight predator control, by HNAN, of these populations. This eventuality should have been reflected in some treatment effect on the predator population, HNAN, or at least parallel trends between HNAN and their photosynthetic counterpart, PNAN, since these 2 populations are likely subjected to common predators. However, in all the experiments, there were no
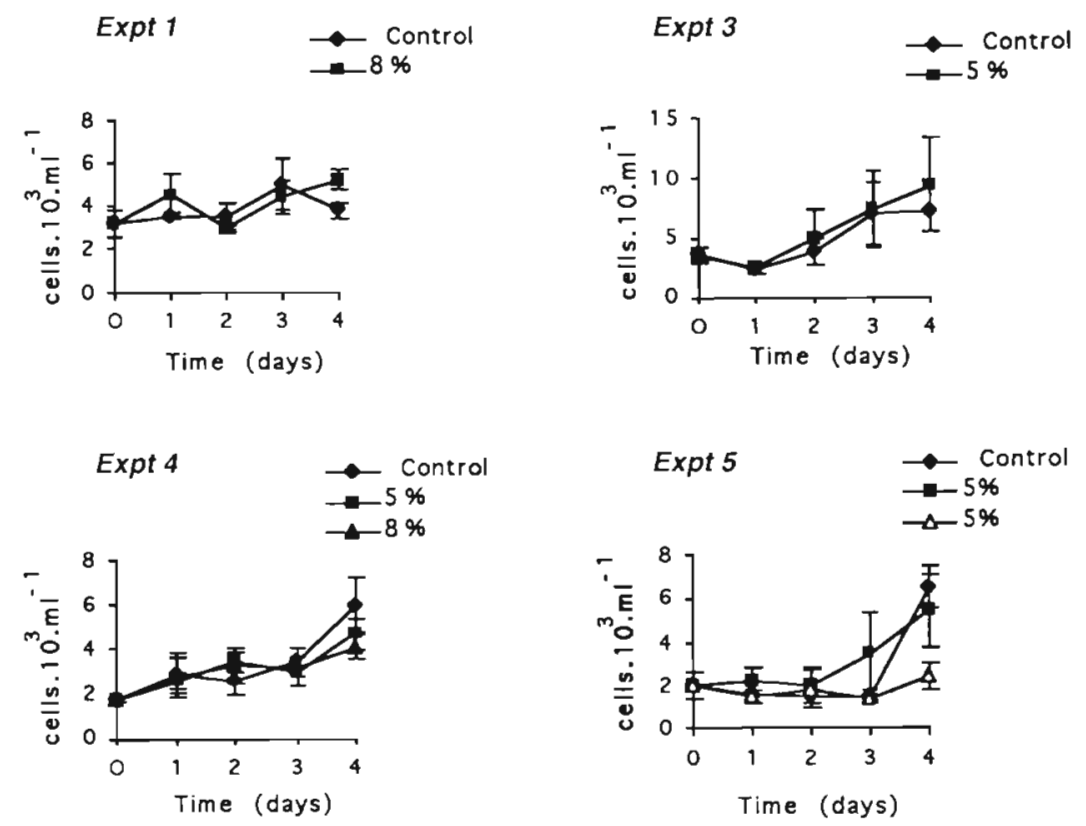

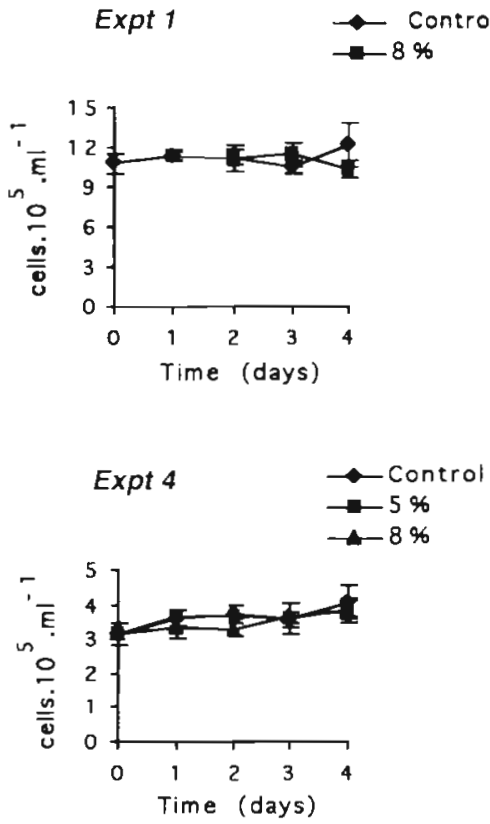
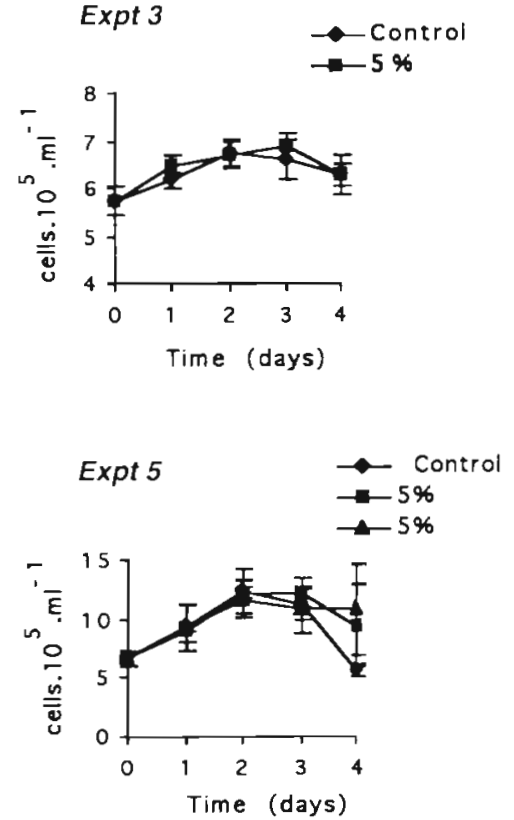

Fig. 5. Temporal changes in abundance of heterotrophic bacteria in the bioassay experiments, Expt 2 excepted. Percentages refer to rain dilution factors, see text and Table 2 for details

treatment effects with regard to HNAN concentrations, which is similar to findings for cyanobacteria and heterotrophic bacteria. We believe the likely explanation for our findings is that, relative to PNAN, neither cyanobacteria nor heterotrophic bacteria reacted significantly to the addition of rainwater.

Our findings with regard to which component of the microbial food web profits from rainwater nutrients were unexpected. Among unicellular organisms, which includes PNAN, CYANO and heterotrophic bacteria, there are basic similarities in mechanisms of nutrient uptake but considerable differences in terms of surface to volume ratios because of differences in cell size. Due in large part to high surface to volume ratios, cyanobacteria or heterotrophic bacteria can efficiently compete with larger phytoplankton cells such as PNAN for mineral nutrients under low nutrient concentration levels, both in the case of $\mathrm{P}$ (Currie \& Kalff 1984, Bratbak \& Thingstad 1985) and N (Wheeler \& Kirchman 1986, Furhman et al. 1988) limitation. Thus, we had expected increases in either CYANO or heterotrophic bacteria in our rainwater-amended experiments to be large relative to changes in either chl $a$ or PNAN

With regard to the coccoid cyanobacteria, it is tempting to speculate that the lack of a response indicates a lack of $\mathrm{N}$-limitation, perhaps due to an ability to fix atmospheric N. However, studies thus far have failed to produce evidence of $\mathrm{N}$-fixation in free-living marine Synechococcus species of cyanobacteria in nature (Zehr 1995). In other oligotrophic systems, Synechococcus blooms have been closely linked to transient increases in concentrations of nitrate (Glover et al. 1988), arguing against a capability to fix nitrogen. Furthermore, in the Bay of Villefranche. previous field investigations have found Synechococcus cyanobacteria to react positively to the presence of excretion products of protistan grazers (Ferrier-Pagès \& Rassoulzadegan 1994). Concentrations of cyanobacteria in the Bay of Villefranche have been closely correlated with bulk ammonium uptake rates (Selmer et al. 1993). Therefore, perhaps the simplest explanation for our findings concerning the lack of a response of bacteria, whether heterotrophic or autotrophic, is that while nitrogen concentrations were too low for reliable detection by our methods, concentrations were sufficient for the picoplankton-sized cells. The populations of CYANO and heterotrophic bacteria were then not stimulated because they were limited by the availability of some other element, probably phosphorus (e.g. Thingstad et al. 1998).

In conclusion, our work suggests that nutrients delivered to the NW Mediterranean via the spring rainfall events benefit eucaryotic phytoplankton, photosynthetic nanoflagellates, rather than autotrophic or het-

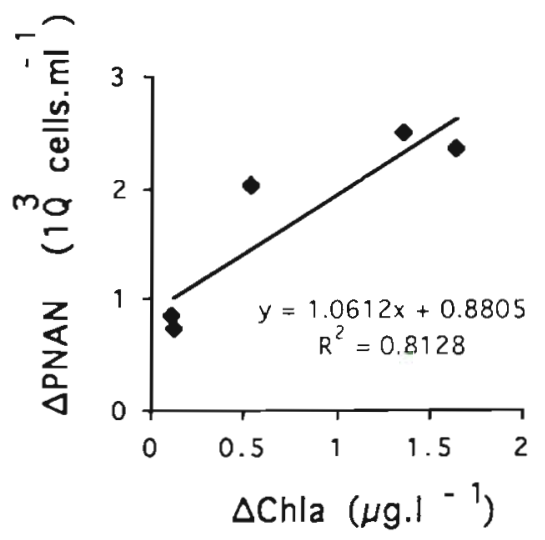

Fig. 6. Correlation between the chl a and PNAN variations (relative to control) after $48 \mathrm{~h}$ incubation in the experiments in which significant changes in chl a concentrations were observed. See Table 2 for details 
erotrophic bacterial populations, the dominant picoplankton populations. We found that increases in chl a resulting from the additions of 'new' rain-borne nutrients were not related in a simple fashion to the quantities of $\mathrm{N}$ added. Furthermore, the phytoplankton population stimulated was not the population usually associated with injections of 'new' nutrients, generally assumed to be diatoms (i.e. Goldman 1993). Thus, our findings indicate that nutrient pathways, at least in oligotrophic systems such as the NW Mediterranean, are difficult to predict in advance. We urge caution in attempting to predict the results of increases in nutrient concentrations when dealing with complex microbial communities.

Acknowledgements. The research reported here is based on a thesis submitted in partial fulfilment of the requirements for a PhD degree in Biological Oceanography, University of Paris VI. Financial support was provided by funding from the CNRS, the CEC grant MS3-CT95-0016 (MEDEA). We are grateful to Marie-Dominique Pizay for technical assistance in nutrient analysis and for the comments of Urania Christaki and 3 anonymous reviewers on previous versions of this paper

\section{LITERATURE CITED}

Azam F, Fenchel T, Field JG, Gray JS, Meyer-Reil LA, Thingstad TF (1983) The ecological role of water-column microbes in the sea. Mar Ecol Prog Ser 10:257-263

Bergametti GE, Remoudaki E, Losno R, Steiner E, Chatenet B (1992) Source, transport and deposition of atmospheric phosphorus over the Northwestern Mediterranean. J Atmos Chem 14:501-513

Berland BR, Bonin DJ, Maestrini SY (1978) Facteurs limitants la production primaire des eaux oligotrophes d'une aire côtière méditerranéenne (Calanque d'En-Vau, Marseille). Int Rev Ges Hydrobiol 63:501-531

Berland BR, Bonin DJ, Maestrini SY (1980) Azote ou phosphore? Considérations sur le 'paradoxe nutritionnel' de la mer Méditerranée. Oceanol Acta 3:135-141

Bernard $F$ (1956) Eaux atlantiques et méditerranéennes au large de l'Algérie. Ann Inst Océanogr 31:232-335

Bratbak G, Thingstad TF (1985) Phytoplankton-bacteria interactions: an apparent paradox? An analysis of a model system with both competition and commensalism. Mar Ecol Prog Ser 25:23-30

Buijsman E, Maas HFM, Asman WAH (1987) Anthropogenic ammonia emissions in Europe. Atmos Environ 21: 1009-1020

Codispoti LA (1989) Phosphorus vs. nitrogen limitation of new and export production. In: Berger WH, Smetacek VS, Wefer G (eds) Productivity of the ocean: present and past. John Wiley \& Sons Ltd, San. Francisco, p 377-394

Currie DJ, Kalff J (1984) A comparison of the abilities of freshwater algae and bacteria to acquire and retain phosphorus. Limnol Oceanogr 29:298-310

Dolan JR, Thingstad TF, Rassoulzadegan F (1995) Phosphate transfer between size-fractions in Villefranche Bay (NW Mediterranean Sea), France in autumn 1992. Ophelia 41: $71-85$
Donaghay PL, Liss PS, Duce RA, Kester DR, Hanson AK, Vil lareal T, Tindale NW, Gifford DJ (1991) The role of episodic nutrient inputs in the chemical and biological dynamics of oceanic systems. Oceanography 4:62-69

Duce RA (1986) The impact of atmospheric nitrogen, phosphorus and iron species on marine biological productivity. In: Menard P (ed) The role of air-sea exchange in geochemical cycling. D Reidel Publ Co, Berlin, p 497-529

Duce RA, Liss PS, Merrill JT, Buat-Menard P, Hicks BB, Miller JM, Prospero JM, Arimoto R, Church TM, Ellis W, Galloway JN, Hanson L, Jickells TD, Knapp AH, Rienhart KH, Schneider B, Soudine A, Tokos JJ, Tsunogai S, Wollast R, Zhou M (1991) The atmospheric inputs of trace species to the world ocean. Global Biogeochem Cycles 5:193-259

Dugdale RC, Goering JJ (1967) Uptake of new and regenerated forms of nitrogen in primary productivity. Limnol Oceanogr 12:196-206

Eppley RW (1989) New production: history, methods, problems. In: Berger WH, Smetacek VS, Wefer G (eds) Productivity of the ocean: present and past. John Wiley \& Sons Ltd, San Francisco, p 377-394

Eppley RW, Peterson BJ (1979) Particulate organic matter flux and planktonic new production in the deep ocean. Nature 282:677-680

Fanning KA (1989) Influence of atmospheric pollution on nutrient limitation in the ocean. Nature 339:460-463

Ferrier-Pagès C, Rassoulzadegan F (1994) Seasonal impact of the microzooplankton on pico- and nanoplankton growth rates in the northwest Mediterranean Sea. Mar Ecol Prog Ser 108:283-294

Fiala MG, Cahet G, Jacques G, Neveux J, Panouse M (1976) Fertilisation de communautés planctoniques. I. Cas d'un milieu oligotrophique: Méditerranée nord-occidentale. J Exp Mar Biol Ecol 24:151-163

Fisher DC, Oppenheimer MP (1991) Atmospheric nitrogen deposition and the Chesapeak Bay estuary. Ambio 20: $102-108$

Fuhrman JA, Horrigan SG, Capone DG (1988) Use of ${ }^{13} \mathrm{~N}$ as tracer for bacterial and algal uptake of ammonium from seawater. Mar Ecol Prog Ser 45:271-278

Galloway JN, Likens GE, Hawley ME (1984) Acid precipitation: natural versus anthropogenic components. Science 226:829-831

Glover HE, Prézelin B, Campbell L, Wyman M, Garside C (1988) A nitrate-dependent Synechococcus bloom in surface Sargasso Sea water. Nature 331:161-163

Goldman JC (1993) Potential role of large oceanic diatoms in new primary production. Deep Sea Res 40:159-168

Jickells T (1995) Atmospheric inputs of metals and nutrients to the oceans: their magnitude and effects. Mar Chem 48: $199-214$

Knap A, Jickelis T (1986) Significance of atmospheric-derived fixed nitrogen on productivity of the Sargasso Sea. Nature 320:158-160

Legendre L, Rassoulzadegan F (1995) Plankton and nutrient dynamics in marine waters. Ophelia 41:153-172

Legendre L, Rassoulzadegan F (1996) Food-web mediated export of biogenic carbon in oceans: hydrodynamic control. Mar Ecol Prog Ser 145:179-193

Lorenzen CJ (1966) A method for continuous measurement of in vivo chlorophyll concentrations. Deep Sea Res 13: 223-227

Loÿe-Pilot MD, Martin JM, Morelli J (1990) Atmospheric input of inorganic nitrogen to the Western Mediterranean. Biogeochemistry 9:117-134

Loÿe-Pilot MD, Morelli J (1988) Fluctuations of ionic composition of precipitations collected in Corsica related to 
changes in the origins of incoming aerosols. J Aerosol Sci 19:577-585

Mallin MA, Paerl HW, Rudek J, Bates PW (1993) Regulation of estuarine primary production by watershed rainfall and river flow. Mar Ecol Prog Ser 93:199-203

Malone TC (1980) Algal size. In: Morris I (ed) Physiological ecology of phytoplankton. Blackwell Scientific Publications, London, p 433-464

Martin JM, Elbaz-Poulichet F, Guieu C, Loye-Pilot MD, Han $G$ (1989) River versus atmospheric input of material to the Mediterranean sea: an overview. Mar Chem 28:159-182

Menzel DW, Spaeth JP (1962) Occurrence of ammonia in Sargasso Sea waters and in rainwater at Bermuda. Limnol Oceanogr 7:159-162

Michaels AF, Siegel DA, Johnson RJ, Knap AH, Galloway JN (1993) Episodic input of atmospheric nitrogen to the Sargasso Sea: contributions to new production and phytoplankton blooms. Global Biogeochem Cycles 7:339-351

Migon C, Copin-Montegut G, Elegant L, Morelli J (1989) Etude de l'apport atmosphérique en sels nutritifs au milieu côtier méditerranéen et implications biogéochimiques. Oceanol Acta 12:187-191

Owens NJP, Galloway JN, Duce RA (1992) Episodic nitrogen deposition to oligotrophic oceans. Nature 315:397-399

Paerl HW (1985) Enhancement of primary production by nitrogen enriched acid rain. Nature 316:747-749

Paerl HW (1993) Emerging role of atmospheric nitrogen deposition in coastal eutrophication: biogeochemical and trophic perspectives. Can J Fish Aquat Sci 50:2254-2269

Paerl HW (1995) Coastal eutrophication in relation to atmopheric nitrogen deposition: current perspectives. Ophelia 41:237-259

Paerl HW, Fogel ML (1994) Isotopic characterization of atmospheric nitrogen inputs as sources of enhanced primary production in coastal Atlantic Ocean waters. Mar Biol 119: 635-645

Paerl HW, Rudek J, Mallin MA (1990) Stimulation of phytoplankton production in coastal waters by natural rainfall inputs: nutritional and trophic implications. Mar Biol 107: $247-254$

Pomeroy LR, Wiebe WJ (1988) Energetics of microbial food webs. Hydrobiologia 159:7-18

Porter KG, Feig YS (1980) The use of DAPI for identifying and counting aquatic microflora. Limnol Oceanogr 2.5 : 943-948

Rassoulzadegan F (1993) Protozoan patterns in the AzamAmmerman's bacteria-phyto mutualism. In: Guerrero R, Pedros-Alio C (eds) Trends in microbial ecology. Spanish Society for Microbiology

Rendell AR, Ottley CJ, Jickells TD, Harrison RM (1993) The atmospheric input of nitrogen species to the North Sea. Tellus 45B:53-63

Rodier J (1976) L'analyse de l'eau, Tome 1. Dunod Ed, Paris

Ryther JH, Dunstan WM (1971) Nitrogen, phosphorus and eutrophication in the coastal marine environment. Science 171:1008-1013

Sciandra A, Gostan J, Collos Y, Descolas-Gros C, Le-

Editorial responsibility: Otto Kinne (Editor),

Oldendorf/Luhe, Germany boulanger $C$, Martin-Jezequel $V$, Denis $M$, Lefevre $D$, Copin C, Avril B (1997) Growth compensating phenomena in continuous cultures of Dunaliella tertiolecta limited simultaneously by light and nitrate. Limnol Oceanogr (in press)

Selmer JS, Ferrier-Pages C, Cellario C, Rassoulzadegan F (1993) New and regenerated production in relation to the microbial loop in the NW Mediterranean Sea. Mar Ecol Prog Ser 100:71-83

Sherr EB, Sherr BF, Paffenhöfer GA (1986) Phagotrophic protozoa as food for metazoans: a 'missing' trophic link in marine pelagic food webs? Mar Microb Food Webs 1. $61-80$

Solarzano L (1969) Determination of ammonium in natural waters by the phenolhypochlorite method. Limnol Oceanogr 14:799-801

Spokes L, Jickells $T_{1}$ Rendell A, Schultz M, Rebers A, Dannecker W, Kruger O, Leermarkers M, Bayens W (1993) High atmospheric nitrogen deposition events over the North Sea. Mar Pollut Bull 26:698-703

Suttle CA, Fuhrman JA, Capone DG (1990) Rapid ammonium cycling and concentration-dependent partitioning of ammonium and phosphate: implications for carbon transfer in planktonic communities. Limnol Oceanogr 35: $424-433$

Thingstad TF, Hagström A, Rassoulzadegan F (1997) Accumulation of degradable DOC in surface waters: Is it caused by a malfunctioning microbial loop? Limno] Oceanogr 42:398-404

Thingstad TF, Rassoulzadegan F (1995) Nutrient limitations, microbial food webs, and 'biological pumps': suggested interactions in a P-limited Mediterranean. Mar Ecol Prog Ser 117:299-306

Thingstad TF, Zweifel UL, Rassoulzadegan F (1998) Indications of P-hunger/P-limitation for both phytoplankton and heterotrophic bacteria in NW Mediterranean summer surface waters. Limnol Oceanogr (in press)

Tréguer P, Le Corre P (1975) Manuel d'analyse des sels nutritifs dans l'eau de mer (utilisation de l'AutoAnalyser II Technicon $\left.{ }^{(}\right)$, 2nd edn. Univ. de Bretagne Occidentale, Brest

Wheeler PA, Kirchman DL (1986) Utilization of inorganic and organic nitrogen by bacteria in marine systems. Limnol Oceanogr 31:998-1009

Willey JD, Cahoon LB (1991) Enhancement of chlorophyll a production in Gulf Stream surface water by rainwater nitrate. Mar Chem 34:63-75

Willey JD, Paerl HW (1993) Enhancement of chlorophyll a production in Gulf Stream surface seawater by synthetic versus natural rain. Mar Biol 116:329-334

Zehr JP (1995) Nitrogen fixation in the sea: why only Trichodesmium? In: Joint IR (ed) Molecular ecology of aquatic microbes NATO ASI Series, Vol G38. SpringerVerlag, Berlin, p 333-364

Zweifel UL, Norrman B, Hagström A (1993) Consumption of dissolved organic carbon by marine bacteria and demand for inorganic nutrients. Mar Ecol Prog Ser 101:23-32

Submitted: March 26, 1997; Accepted: October 2, 1997 Proofs received from author(s): November 4, 1997 